\title{
ANTROPOLOGICZNE WĄTKI BIBLIOLOGII JANUSZA DUNINA
}

Od wynalezienia pisma po dzień dzisiejszy książka wiąże ze sobą wszystkie dziedziny kultury duchowej [...] Ona uczestniczy w tak istotnym dla istnienia i rozwoju zbiorowości społecznej procesie, jak przekazywanie tradycji i upowszechnianie jej wartości.

Karol Głombiowski ${ }^{1}$

Niemniej jednak upłynnienie podmiotu myślącego [...] wraz ze świadomością wymiany symbolicznej jako podłoża świata i myśli, destabilizuje dyskurs porządku i racjonalizacji, w tym również dyskurs naukowy.

Jean Baudrillard ${ }^{2}$

I.

Przełomy stuleci zachęcają do ocen i podsumowań dorobku naukowego dyscyplin, instytucji i poszczególnych uczonych. Z tej refleksji wynika namysł nad dorobkiem Janusza Dunina, uczonego, który w swych badaniach nad książką łączył kilka równoległych dyskursów: bibliologiczny, bibliofilski i komunikacyjny. Stanowiło to wynik fascynacji kulturową różnorodnością produktów wydawniczych i bodziec do identyfikowania odmienności w obrębie universum książki. Dunina interesowały w szerokim rozumieniu

${ }^{1}$ K. Głombiowski, Czy bibliologia może się wybić na samodzielność? (W odpowiedzi moim czytelnikom - rzeczywistym i urojonym), „Roczniki Biblioteczne” 1983 R. 27, z 1-3, s. 598.

2 J. Baudrillard, Słowa klucze, przeł. S. Królak Warszawa 2008, s. 71. 
społeczne konteksty funkcjonowania publikacji i ewolucje strategii konsumpcyjnych w odniesieniu do czytania jako czynności ludzkiej. Dorobek tego uczonego pod wieloma względami stanowi wyzwanie dla współczesnych badaczy, bowiem jego analiza nasuwa spostrzeżenia o szczególnym „przejściu” od teorii form książki do antropologii słowa ${ }^{3}$.

Polskie osiągnięcia w zakresie szeroko rozumianej antropologii słowa wyrastają z tradycji literaturoznawczej i etnologicznej. W swoich rozważaniach nad funkcjonowaniem różnych ewolucyjnych form pisma, badacze uwzględniają przede wszystkim perspektywę komunikacyjną. Traktują oni pismo jako jedno z najważniejszych mediów, którego rozumienie i sposób funkcjonowania powinny być zestawiane $\mathrm{z}$ medialnością żywego słowa, druku i przekazów elektronicznych. Współcześnie badacze z tego kręgu, sytuując pismo głównie w kontekstach antropologicznym i historycznym, analizują jego wpływ na sposób myślenia, doświadczenia, kategoryzowania świata, kształt więzi społecznych i tożsamości jednostki. Takie podejście pozwala dostrzec semantyczny i semiotyczny wymiar piśmienności - pismo jako nośnik znaków i znaczeń - ale także wymiar praktyczny i perfomatywny - pismo jako działanie słowem ${ }^{4}$.

\section{II.}

Wątki antropologiczne w bibliologii nie są zagadnieniem zupełnie nowym. Klasyk badań nad społecznym funkcjonowaniem książki, Robert Escarpit, twierdził, że literatura nie jest sztuką czystą, a litera (alfabet), która stanowi jej specyficzne (choć nie pierwotne) medium i od której pochodzi jej nazwa, jest jednocześnie przedmiotem i znakiem. „Skoro zaś traktujemy książkę jako przedmiot artystyczny - pisał Escarpit - a tekst (w sensie jego materialnej konkretyzacji) jako jeden z elementów tego przedmiotu, rozpa-

\footnotetext{
3 Autor pisał już na temat dorobku uczonego. Zob.: J. Ladorucki, Janusz Dunin: badacz osobny. Uwagi o cechach metody naukowej i bibliologii otwartej uczonego. "Roczniki Biblioteczne” 2013, t. 57, s. 103-112; Dorobek Dunina jest obecny we współczesnym dyskursie naukowym. Po śmierci uczonego ukazała się księga okolicznościowa, w której znalazło się kilka tekstów poświęconych jego dokonaniom: Pasja książki. Studia poświęcone pamięci profesora Janusza Dunina, red. J. Ladorucki, M. Rzadkowolska, Łódź 2009. W kontekście zagadnień niniejszego artykułu na szczególną uwagę zasługują wypowiedzi Krzysztofa Migonia Teoria książki w ujęciu Janusza Dunina (s. 14-25) i Tadeusza Żabskiego, Janusz Dunin - współtwórca nauki o literaturze popularnej (s. 26-34). Por. też rec. M. Skalska-Zlat, „Roczniki Biblioteczne” 2010, nr 54, s. 242-249. i H. Tadeusiewicz. „Annales Universitatis Paedagogicae Cracoviensis Studia ad Bibliothecarum Scientiam Pertinentia" 2010, Vol. 8, s. 249-253

${ }^{4}$ Pisali o tym m.in. Phillipe Artieres i Paweł Rodak we Wstępie do Antropologii pisma. Od teorii do praktyki, Warszawa 2010, s. 9-14.
} 
trywać ją musimy jako podległą prawom całej sieci warunków społecznych rządzących rozpowszechnianiem przedmiotów artystycznych, takich jak obrót, lokata kapitału, fetyszyzm, konsumpcja na pokaz, poszukiwanie tzw. status symbol itp."

Przedstawiciel polskiej szkoły bibliologicznej, Karol Głombiowski, postulował w swoich pracach, aby naukę o książce rozumieć jako naukę o człowie$\mathrm{ku}$, a podstawową metodę bibliologii, nazwaną „funkcjonalną” posługiwać się jako narzędziem badania książki traktowanej jako zespół wszystkich jej elementów pozostających w związkach z czytelnikiem, czyli z człowiekiem ${ }^{6}$. Według Głombiowskiego charakterystyczny dla nauki o książce jest pewien progresywny układ świadomych i celowych działań zmierzających do upowszechniania treści kulturowych ${ }^{7}$. Bibliologia zatem „usiłuje dostrzec (...) i przedstawić świadomy wysiłek ludzki w kształtowaniu życia społecznego, próbuje dotrzeć do jego wartości duchowych, pragnie ujawnić piękno tego przeżycia, które człowiek zawdzięcza książce. Wybierając naukę o książce przekonywał Głombiowski - wybieramy historię ludzką .

Przed kilkoma laty, współczesny badacz, Andrzej Dróżdż, otwierając na nowo dyskusje nad powinowactwami bibliologii, podkreślał, iż antropologia kulturowa jest dziś szczególnie potrzebna. Służy przede wszystkim akcentowaniu wartości czytania, uniwersalnym potrzebom psychospołecznym wynikającym z uprawiania lektury i jej roli w tworzeniu nauki. Dodawał także, iż dzisiejszej bibliologii niezbędna jest determinacja do podjęcia dyskusji kulturowej i poszerzanie metod i tematów badawczych ${ }^{9}$. Wśród współczesnych humanistów zajmujących się zagadnieniami społecznego funkcjonowania słowa istnieją znaczące różnice w pojmowaniu przedmiotu badań. Jednak częste odwoływania do Herberta Marshalla MacLuhana, Harolda Innisa, Erica Havelocka, Waltera J. Onga i Jacka Goody`ego tworzą wspólny obszar badawczy, w którym, jak się zdaje, mieści się także pewna część bibliologii i twórczości naukowej takich badaczy jak Janusz Dunin.

\footnotetext{
${ }^{5}$ R. Escarpit, Rewolucja książki, przeł. J. Pański, Warszawa 1969, s. 31.

${ }^{6}$ Zob.: K. Głombiowski, O funkcjonalną koncepcję nauki o książce "Studia o Książce” 1970, t. 1 s. $5-24$.

${ }^{7}$ K. Głombiowski, Czy bibliologia może się wybić na samodzielność? (W odpowiedzi moim czytelnikom - rzeczywistym i urojonym), „Roczniki Biblioteczne”1983 R. 27, z 1-3, s. 579.

${ }^{8}$ I dalej: „,wybieramy historię książki, którą świadomy trud człowieka czyni pełnym urody naczyniem swoich myśli i swoich uczuć" K. Głombiowski, Problemy historii czytelnictwa, Wrocław 1966, s. 39.

${ }^{9}$ A. Dróżdż, Książki i biblioteki w perspektywie antropologii kulturowej [w:] Bibliologia i informatologia pod red. Dariusza Kuźminy, Warszawa, 2011, s. 65-79.
} 
III.

Warto na początku zadać pytanie, czy rozwój bibliologii kreuje nowy obszar, który można nazwać „antropologią książki”? Prawdopodobnie rozważania bibliologiczne od zawsze były nasycone pierwiastkami antropologicznymi, bowiem obcowanie $\mathrm{z}$ książką jest czynnością ludzką. Zwrot w kierunku antropologii książki oznaczałby jednak wchodzenie w specyfikę warsztatu antropologicznego, który bibliologom nie był dotychczas potrzebny do efektywnego prowadzenia badań nad kulturą książki. Zatem „antropologia książki”, choć brzmi obiecująco, w gruncie rzeczy sugeruje przeniesienie kompetencji w zakresie badania książki w inne obszary nauk społecznych; zastąpienie nią tradycyjnej bibliologii odwraca dotychczasowe polaryzacje i paradoksalnie kłóci się z ideą transdyscyplinarności dominującej we współczesnej humanistyce. Wobec tego niesłychanie przydatna wydaje się a ntropologizacja dyskursu bibliologicznego i kontekstualne próby poszerzania pespektyw odczytań faktów z historii i współczesności kultury książki ${ }^{10}$. W praktyce powinno to oznaczać większe skupienie na:

- sytuowaniu zjawisk książki w szerokim spektrum kultury,

- kontekstowości (historycznej i podmiotowej) podejścia badawczego, czyli nastawienie na pewne cechy wiedzy bibliologicznej,

- refleksyjności w odniesieniu do procesu poznawczego wraz z jego uwikłaniami,

- systemowości, polegającej na holistycznym podejściu do spektrum połączonych ze sobą elementów.

Przekraczanie granic jest w nauce stanem normalnym i koniecznym dla rozwoju, a bibliologia nie może uniezależniać się od zdobyczy humanistyki ostatnich lat. W tym wypadku badanie granic dyscypliny nie oznacza naruszania jej integralności ani spójności. Przeciwnie, pozostające w centrum nauki o książce, dotychczasowe dokonania naukowe i podstawowe dzieła Jana Muszkowskiego, Stefana Vrtela-Wierczyńskiego, Mieczysława Rulikowskiego, Kazimierza Piekarskiego, Adama Łysakowskiego, Karola Głombiowskiego i innych dawniejszych oraz współczesnych teoretyków, gwarantują bibliologii spójność i pozwalają na „testowanie” nowych obszarów, bez ryzyka utraty tożsamości dyscypliny.

${ }^{10} \mathrm{~W}$ piśmiennictwie badaczy kultury spoza bibliologii zdarzają się publikacje dotyczące antropologizacji różnych dziedzin nauk humanistycznych (historii, językoznawstwa, literaturoznawstwa $\mathrm{i}$ innych), ale autor niniejszego artykułu nie natknął się na materiały postulujące antropologizację bibliologii autora spoza kręgu badan księgoznawczych. 
Pewne jest, że zantropologizowana w tych granicach bibliologia pozostanie zawsze bibliologią ${ }^{11}$.

W tym kontekście twórczość naukowa Dunina, skupiona na badaniu kulturowej różnorodności świata książki, stanowi dla badacza ciekawe pole rozważań nad statusem i kondycją współczesnej nauki o książce. Antropologiczne wątki bibliologii Dunina ujawniały się wtedy, gdy - za pomocą warsztatu bibliologa (!) - badacz pokazywał rozwój i mitologizację kultury widoczną w masowej wydawniczej produkcji literacko-kabaretowej, wzajemnych wpływach środków przekazu na cechy książki, obiegach literackich czy w dziejach książki powiązanych ściśle z jej funkcjami społecznymi.

Zainteresowanie uczonego historią kultury masowej, socjologii książki i czytelnictwa kierowało go od początku drogi naukowej na nowe, niezbadane obszary, niezauważane lub lekceważone przez innych. Wśród nich znalazły się wydawnictwa popularne, tandetne druki kramarskie i brukowe, przeznaczone dla niewprawnego czytelnika. W pewnym okresie badacz spostrzegł, iż

Modne ostatnio zainteresowanie dla sztuki naiwnej, dla artystycznego prymitywu kieruje uwagę na skromne płody jarmarcznej i podwórkowej muzy. Były one najczęściej pomijane przez oficjalną historię literatury i wiele opracowań bibliograficznych bądź ze względu na z góry założoną selekcję materiału bezwartościowego, bądź z powodu nieuchwytności tego typu wydawnictw $[\ldots]^{12}$.

Tak rozpoczęło się badanie meandrów kultury przy wykorzystaniu bibliologicznej metodologii. Zaznaczyć należy, że Dunin interesował się książką nie tylko jako źródłem informacji i rozrywki i nie tylko samym tekstem, ale książką jako „nośnikiem tego wszystkiego, co spełnia własną rolę komunikacyjną ${ }^{13}$.

${ }^{11}$ W podobnym tonie wypowiada się Dróżdż, gdy pisze: „Zróżnicowanie szkół, kierunków i odmian antropologii jest tak wielkie, że postępujący wśród nauk społecznych i humanistycznych proces antropologizacji należy traktować raczej jako świadectwo pewnej dyspozycji do dialogu; dyspozycji, która nie wymaga deklaracji lojalności ani wnikania we wszystkie dylematy definicyjne i metodologiczne. Zetknięcie się odrębnych koncepcji badawczych antropologii zachęca do myślenia w kategoriach wzajemnych uzupełnień, a nie dzielących przepaści” A. Dróżdż, op. cit, s. 68.

${ }_{12}$ J. Dunin, Warsztat bibliograficzny i biblioteczny badacza literatury tandetnej, „Studia o Książce" 1970, t. 1 s. 117.

13 J. Ladorucki, Pozostawałem w kręgu książki.. Rozmowy z profesorem Januszem Duninem o bibliologii, medioznawstwie i zwyczajnym życiu, Łódź 2007, s. 17. 


\section{IV.}

Dla Dunina jako księgoznawcy i literaturoznawcy istotne badawczo były jedynie wypowiedzi językowe utrwalone na dowolnym nośniku. Badacz akcentował społeczny wymiar i performatywność literatury / książki (choć nie używał tego terminu) i podkreślał, że tekstem może być niemal wszystko, co jest w kulturze powtarzalne (i społecznie przekazywane). Twierdził, że z pojęciem tekstu związane są określenia wzorca i pochodnych, dlatego

mówimy [...] o tekstach wobec czegoś identycznych, wiernych, poprawionych, skróconych itp. Jednorazowe zapisanie jakiegoś utworu, nawet jeśli przeczytało go kilka osób, nie jest jeszcze w pełni jego rozpowszechnieniem - zjawisko to następuje wtedy, gdy zostaje on w tym celu powielony. Stykając się z różnymi postaciami tekstów - szczególnie dawnych - trudno niekiedy określić, czy znajdowały się one kiedykolwiek w obiegu społecznym. Pewnych wskazówek dostarczyć nam jednak mogą różnorodne sygnały, zarówno wewnątrztekstowe, jak i zawarte w materialnej formie przekazu, mówiące o istnieniu intencji jego rozpowszechniania ${ }^{14}$.

Łódzki badacz opisywał często świat druków, którym się fascynował w kategoriach „wydarzenia piśmiennego". Termin ten zaproponowany przez Beatrice Fraenkel ma dwa podstawowe znaczenia. Pierwsze nawiązuje do „aktu zerwania” i swoistych ingerencji w rzeczywistość (np. murale); w drugim znaczeniu „wydarzenie piśmienne” stanowi sekwencję życia społecznego, które organizuje się wokół używania tekstów ${ }^{15}$. W tym ostatnim sensie mieszczą się między innymi rozważania badacza wokół odpisów tekstów w działalności podziemnej opozycji politycznej w latach PRL-u. Ten rodzaj przekazu wynikał nie tyle $\mathrm{z}$ chęci utrwalania myśli, co z pragnienia działania poprzez pismo:

Niezależna myśl i literatura różnych obiegów powróciła na całe lata do tradycyjnych form kopiowania. Czasem były to odpisy rękopiśmienne, częściej przebitkowe na maszynie - wytworzyła się wręcz specyficzna literatura sekretarek, które w wolnej chwili przepisywały parę stron, a następnie teksty te rozdawały przyjaciółkom [...] Najwięcej jednak rozchodziło się wierszy,

14 J. Dunin, Odpis jako forma rozpowszechniania tekstów [w:] Piśmiennictwo-systemy kontroli-obiegi alternatywne, t. 2, pod red. J. Kosteckiego i A. Brodzkiej, Warszawa 1992, s. 151.

${ }_{15}$ Zob. na ten temat: B. Fraenkel, Pojęcie wydarzenia piśmiennego [w:] Antropologia pisma. Od teorii do praktyki, red. Ph. Artieres, P. Rodak, Warszawa 2010, s. 68-70. 
zarówno tych najwyższej klasy, jak i najniższego lotu. Jeszcze niedawno widziałem odpis bardzo prymitywnego wierszyka politycznego z informacją, a ściślej, dezinformacją, że autorem jest... Czesław Miłosz ${ }^{16}$.

Dunin posiadał wypracowane $\mathrm{w}$ czasie wieloletnich badań i praktyki pracy z książką kompetencje, które pozwalały mu trafnie charakteryzować funkcjonalne cechy publikacji, interakcje czytelnik-lektura i aspekty przemian formalnych świata druków. Ważne, z punktu widzenia wartości naukowej, były jego opisy szczególnych przypadków funkcjonowania świata pisma, np. charakterystyki akcydensów lub sztambuchów. Zauważał np. że w historii

odnotowano szczególny fakt pod nazwą silva rerum - odpisy różnych tekstów, zarówno utworów literackich, jak i przepisów lekarskich oraz rozmaitych informacji - umieszczane w księgach domowych. Zjawisko to wiązano zwykle z okresem upadku książki polskiej w XVII i w początkach XVIII w. $\mathrm{W}$ owych silva rerum zachowało się zresztą wiele tekstów nie znanych $\mathrm{z}$ innych źródeł. W późniejszym czasie tradycja odpisów trwała, rzadko ją jednak zauważano, a biblioteki lekceważyły materiały, które nie zawierały elementów oryginalnych. Żywsze zainteresowanie budziły jedynie sztambuchy, zwłaszcza zawierające rękopisy klasyków. Do sztambuchów nie wpisywano na ogół tekstów już znanych, natomiast powielały je pensjonarskie pamiętniki-imionniki, pełne tradycyjnych, konwencjonalnych wierszyków ${ }^{17}$.

\section{V.}

Z punktu widzenia antropologicznego kryterium refleksyjności ${ }^{18}$ i oceny dokonań tego uczonego istotne jest zagadnienie dystansu do przedmiotu badań, ale i do siebie samego, jako podmiotu poznającego. Dunin bowiem, ulegał pewnej „obiektywizacji przewrotnej”19 - czuł się częścią kultury książki i opisywał ją jako jej użytkownik, próbujący niejednokrotnie uwolnić się od złudzenia naukowości. Posługiwał się jednak sprawnie i skutecz-

\footnotetext{
${ }^{16}$ J. Dunin, Odpis jako forma rozpowszechniania..., s. 158-159.

17 Tamże, s.152-153.

${ }^{18} \mathrm{Na}$ temat refleksyjności zob.: W Kruszelnicki, Zwrot refleksyjny w antropologii kulturowej, Wrocław 2012, s. 30-41.

${ }^{19}$ Określenie zaczerpnięte z artykułu: A. Pomieciński, S. Sikora, Antropologia: ogród o rozwidlających się ścieżkach. Wprowadzenie [w:] Zanikające granice. Antropologizacja nauki i jej dyskursów, red. A. Pomieciński i S. Sikora, Poznań 2009, s. 8.
} 
nie narzędziami, aparatem i terminologią naukową. Liczne tego dowody znajdujemy w Pismo zmienia świat. Lektura. Czytanie. Czytelnictwo, podręczniku akademickim do nauczania zagadnień czytelnictwa, gdzie autor, rozważając stosunek lektury do potrzeb człowieka, wyraził opinię:

Można by tę problematykę zbyć twierdzeniem, że całe gadanie o tym, co jest, a co nie jest naturalne, niewiele jest warte [...]. - i nieco dalej - Wolno sądzić, że pismo a w konsekwencji książka rozwinęła się w wyniku nie tyle wynalazków, ile odkryciu pewnej cechy naddanej człowiekowi [...] Takie cechy mają również zwierzęta, żadna foka nie widziała nigdy plastikowej piłki i nie wie, że może nią dowolnie żonglować nosem, czego nigdy nie potrafią tak obyte z ludzkimi zabawkami pies czy końn ${ }^{20}$.

W całym podręczniku zachowano wiele cech oralnej potoczności, utrzymanej zazwyczaj w trzeciej osobie ${ }^{21}$. Zdarza się jednak i tak, iż autor w odniesieniu do jego prywatnych przypadków, wprowadził ton osobisty, posługując się pierwszą osobą:

Jako pensjonariusz szpitali - przy wszelkich niedogodnościach tej zwykle horyzontalnej pozycji - miałem okazję do obserwacji i rozmów z ludźmi, których nigdy bym w innych okolicznościach nie spotkał. Byli wśród nich funkcjonalni i bezprzymiotnikowi analfabeci, w których codzienności nie mieściły się sprawy książki. Nie był to jednak czas po temu, aby ich w lecznicy nawracać22.

Tego rodzaju narracja w pewnym stopniu obnaża stereotypizację nauki i budzi skojarzenia ze zdobyczami postmodernistycznej antropologii i myślą Jamesa Clifforda ${ }^{23}$. Dość charakterystyczne i wymowne jest, że w swej podstawowej teoretyczno-historycznej pracy nad rozwojem form wydawniczych książki, Dunin podkreśla, iż dla potrzeb tejże rozprawy „najzupełniej wystarczające będzie potoczne zrozumienie, czym jest książka, zjawisko tak dawno i głęboko tkwiące w naszej codzienności, że nawet dziecko potrafi wskazać ją wśród wielu innych przedmiotów" ${ }^{24}$. Podobnych przykładów niestandardowego podejścia, przemilczanego do tej pory przez krytyków, w ca-

20 J. Dunin, Pismo zmienia świat. Lektura. Czytanie. Czytelnictwo, Warszawa-Łódź 1998, s. 14 i 15.

${ }_{21}$ Tamże, s. 8.

22 Tamże, s. 60.

${ }^{23}$ Zob.: J. Clifford, Kłopoty z kulturą, Dwudziestowieczna etnografia, literatura i sztuka, przeł. E. Dżurak, J. Iracka, E. Klekot, M. Krupa, S. Sikora i M. Sznajderman, Warszawa 2000.

${ }^{24}$ J. Dunin: Rozwój cech wydawniczych polskiej książki literackiej XIX-XX wieku. Łódź 1982, s. 9. 
łej twórczości uczonego jest więcej; zwracają również uwagę felietony jego autorstwa, których nie można odczytywać wyłącznie jako marginesu aktywności naukowej. Kieruje to uwagę badacza pism Dunina w stronę postmodernistycznej wieloznaczności i nieokreśloności. Być może jest to dobry moment, aby XX-wieczną spuściznę bibliologii i jej jakość próbować na nowo, zgodnie $\mathrm{z}$ duchem ponowoczesności, rozpoznawać, nazywać i opisywać?

VI.

Kontekstowość, rozumiana jako ujmowanie zjawiska z perspektywy badanej jednostki lub grupy poprzez pryzmat jej obrazu świata i grupowej specyfiki, daje się zauważyć w tekstach uczonego szczególnie wyraźnie, kiedy analizuje on ruch bibliofilski. Zdziwienie mogą wywołać stwierdzenia, iż bibliofilstwo jest zagadnieniem trudnym do zdefiniowania, będącym „raczej kwestią stopnia zainteresowania, niż jego istoty" ${ }^{25}$. Jedno $\mathrm{z}$ najbardziej obiektywnych kryteriów oceny tego zjawiska - według opinii „Księgołapa doskonałego” ${ }^{26}$ - ma stanowić przyjrzenie się ludziom, którzy „deklarują się jako bibliofile i szukają społecznego kontaktu z innymi podobnymi im osobami”27. Analogicznie charakteryzuje bibliofilskie kolekcje, twierdząc, iż trudno ustalić ich kryteria formalne i podkreślając, że najłatwiej jest je zdefiniować na podstawie stosunku zbieracza do druków, w których upatruje szczególną wartość pozamaterialną ${ }^{28}$. Również własną drogę do bibliofilstwa wyjaśnia w typowo kontekstualny sposób:

W czasie wojny nie było praktycznie nowych polskich książek, więc korzystało się z książek od znajomych, ale ponieważ była bieda, ludzie chcieli się ratować, wysprzedawali masowo książki. Lubiłem chodzić do antykwariatu, coś tam kupiłem, ale zawsze grzebałem, przynosiłem pewne książki, których de facto nie czytałem, ale cieszyły mnie, że są, np. Kazimierza Wójcickiego Pokój dziadunia, to taka XIX-wieczna książka dla dzieci. Wówczas chwyciłem się tego bakcyla, można powiedzieć bibliofilskiego, ale bardziej chodziło o oglądanie książek ${ }^{29}$.

${ }^{25}$ C. J. Duninowie: Philobiblon polski. Wrocław 1983 s. 13.

26 Określenie Jerzego Andrzejewskiego zaczerpnięte z: Tenże, Janusz Dunin - uczony, księgołap doskonały [w:] Pasja książki, Studia poświęcone pamięci profesora Janusza Dunina, pod red. J. Ladoruckiego i M. Rzadkowolskiej, Łódź 2009, s. 489-493.

${ }^{27}$ C. J. Duninowie: Philobiblon... s. 5.

${ }^{28}$ Tamże, s. 13.

29 J. Ladorucki: Pozostawałem w kręgu książki... s. 80-81. 
Jako naukowiec Dunin poszukiwał początków swojej drogi w zetknięciu z felietonami Juliana Tuwima. Młodzieńcze lektury Cicer cum caule, czyli groch z kapusta w popularnym piśmie „Problemy”, a potem fascynacja komentarzami literackimi gatunków w Pegazie dęba, otwierały umysł przyszłego naukowca na różnorodność rzadkich druków jarmarcznych, sensacyjnych i dziecięcych. Dość szybko pojawiła się refleksja, że mimo podobieństw, jego zbiór gromadzony poprzez zakupy antykwaryczne, prowadzi go w kierunku innym, niż ten, w którym zmierzał Tuwim:

U niego [u Tuwima - J.L.] był to głównie zbiór ciekawostek, kuriozów i pięknostek, ja zacząłem tu widzieć temat $\mathrm{z}$ historii naszej kultury [...]. Rychło odkryłem, że tzw. literatura niska ma swoich badaczy, zwłaszcza w Niemczech, Francji i Anglii. Moją kolekcję potraktowałem jako inspirację i rozpocząłem systematyczne poszukiwania w piśmiennictwie i różnych zbiorach druków ${ }^{30}$.

Po latach wyznawał, iż nie przypuszczał, że jego życie będzie związane z książką ${ }^{31}$. Studia na Katolickim Uniwersytecie Lubelskim zapoczątkowały wieloletni okres zbieractwa, w którym obok podstawowych dzieł polonistycznych pojawiały się „różne dzieła grafomanów i zapomnianych awangardzistów [...] twory dawnych i nowych satyryków, zbiory anegdot i wiele innych zabawnych dzieł [...], książek dla ludu i pogranicza, na które składają się przede wszystkim powiastki, dziełka umoralniające i pouczające, śpiewniki, senniki, przepowiednie i księgi magii, nieco dewocjonaliów"32.

Nietypowość kolekcjonerstwa Dunina polegała na tym, że nie przywiązywał się do zbiorów, a po opisaniu jakiegoś segmentu kolekcji, pozbywał się go, traktując jako wyczerpaną inspirację do opisu fragmentu papierowego universum.

\section{VII.}

Decydująca dla przyszłych poczynań naukowych Dunina była jego formacja społeczna i intelektualna. Przywiązanie do określonych wartości kulturowych czyniło go polskim inteligentem ukształtowanym na wzorcach cywilizacyjnych przełomu XIX i XX wieku. Specyficzny twór historii spo-

\footnotetext{
30 Tamże, s. 35.

31 Tamże, s. 80.

32 J. Dunin, Moje książki i broszury popularne. Teka aukcyjna nr 1(3) 1999, Z kolekcji Janusza Dunina jarmarczna, brukowa i okolice, Łódź 1999 199, s. VII-X.
} 
łecznej Europy Wschodniej, nazwany inteligencją, określał przywiązanie do wysokich standardów kulturowych, ideałów oświecenia oraz umiłowania wiedzy i talentu. Czynniki te zdecydowały o tym, że warstwa ta zyskiwała na znaczeniu począwszy od lat trzydziestych XIX wieku w peryferyjnie usytuowanych obszarach Europy, a szczególnie w Polsce i Rosji ${ }^{33}$. Po utracie niepodległości, polska inteligencja, żywiąc pragnienie odbudowy niezależności państwowej, dbała o przetrwanie narodu, rozumiejąc, iż gwarantować to może jedynie zachowanie wartości kulturowych. W dwudziestoleciu międzywojennym, kiedy Dunin odbierał wychowanie i edukację, otwarta i laicka, najczęściej piłsudczykowska inteligencja, odgrywała poważną rolę opiniotwórczą a ,jej prominenci byli inicjatorami i organizatorami rozmaitych akcji społecznych” - pisała Barbara Skarga. „Dość wymienić kilka nazwisk: Leon Petrażycki, Marian Zdziechowski, Stefan Czarnowski, Stanisław Ossowski, Florian Znaniecki, cała szkoła lwowsko-warszawska, Tadeusz Boy-Żeleński z jego wspaniałą biblioteką przekładów, Stanisław Ignacy Witkiewicz" ${ }^{34}$.

Dzieciństwo bohatera niniejszego artykułu upływało w typowo inteligenckiej atmosferze, a młodzieńczy sposób postrzegania świata wynikał $\mathrm{z}$ przyjętych $\mathrm{w}$ toku wychowania wartości. We wspomnieniach uczonego powtarza się w związku z tym rodzaj "myślenia etnocentrycznego" 35 i uwidaczniają się więzi kulturowe $\mathrm{z}$ dobrze oswojonym środowiskiem:

Różne były typy bliskości, aby należeć do grupy, nie tylko trzeba było mieszkać niedaleko, ale również spełniać dodatkowe warunki. [...] Eliminowano z bliższych przyjaźni obcych, np. Raimundas był dobrym chłopcem, czasem mieliśmy z nim kontakty, ale to nie było to. [...] Następowały też podziały społeczne, nie chcę powiedzieć, że klasowe, bo przebiegały niezgodnie $\mathrm{z}$ aktualną sytuacją ekonomiczną rodzin. Wydaje się, że tu odrębną grupę stanowiliśmy my, którzy w rodzinnym domu współżyli z książką. Nie izolowaliśmy się celowo, blisko żyliśmy z Józiukami i Pawlukami z naszej ulicy, ale nasze wyobrażenia i zabawy przybierały inny charakter, m.in. ciągle marzyliśmy o wydawaniu własnego czasopisma. Mam 5 numerów rękopiśmiennego periodyku „Start”, który publikowaliśmy w dwóch egzemplarzach z obecnym

${ }^{33} \mathrm{Na}$ temat inteligencji w XIX-wiecznej Europie zobacz hasło: Inteligencja [w:] Słownik literatury polskiej XIX wieku, pod red. J. Bachórza i A. Kowalczykowej, Wrocław-Warszawa-Kraków 1991, s. 373-377.

${ }^{34}$ B. Skarga, Inteligencja zamilkła „Gazeta Wyborcza” 2006, nr 12, s. 10-11.

${ }^{35} \mathrm{Na}$ temat etnocentryzmu i relatywizmu kulturowego, zob.: S. Jedynak, Kategorie kultury, Lublin 2011, s.17-18. 
docentem PAN-u. Pod wpływem lektur przychodziły nam do łbów różne pomysły. Wileński świat książek i gazet był specyficzny. [...] Trwało kilka prywatnych wypożyczalni. Chyba najbardziej znany był księgozbiór na ulicy Tatarskiej prowadzony przez panią Markowską $[\ldots]^{36}$.

Poczucie wspólnoty norm społecznych i bliskości tego, co oferowała kultura wysoka oraz przypisane do niej instytucje życia literackiego dawały przedwojennej inteligencji jasne rozeznanie w kulturowych hierarchiach. Rozwijający się jednak wówczas przemysł rozrywki, wysokonakładowej prasy i zeszytowych serii wydawniczych, stymulował rozkwit miejskiego folkloru, który fascynował kulturową odmiennością inteligentów takich jak Tuwim, a potem Dunin. Na przełomie lat pięćdziesiątych i sześćdziesiątych XX wieku, kiedy przyszły „Profesor od złej literatury”37 miał już za sobą studia polonistyczne i rozeznanie $\mathrm{w}$ kanonie literackim, zaczęły się krystalizować jego zainteresowania wokół książek, które nie zyskiwały pochlebnych opinii wśród uniwersyteckich autorytetów ${ }^{38}$.

Droga naukowa Dunina pokazuje wymiar społeczny księgoznawstwa, otwartość i perspektywę wielości odczytań kultury poprzez książkę w bibliologicznym dyskursie. Otwartość jego bibliologii ujawniała się wówczas, kiedy włączał się w nurt pokrewnych badań, ale odrębnych dziedzin humanistycznych, oferując swój warsztat i ustalenia księgoznawcy, które stanowiły równoprawny składnik odkrycia naukowego. Otwartość była więc próbą wyjścia bibliologa naprzeciw innym dyscyplinom i propozycją korzystania $\mathrm{z}$ wiedzy bibliologicznej podczas badania złożonego świata kultury ${ }^{39}$.

W swojej najgłośniejszej pracy, Papierowym bandycie, uczony ujawnia się właśnie jako bibliolog badający literaturę, w której dzieła interesowały go mniej jako teksty literackie a bardziej jako publikacje, druki, broszury, książki. Warsztat polonistyczny, który odebrał podczas studiów był w tym s. 30 .

${ }^{36}$ J. Dunin-Horkawicz, Co było a nie jest... Czyli kilka lat młodości mojej w Wilnie, Łódź 1990,

${ }^{37}$ Określenie Igora Rakowskiego-Kłos z artykułu: Tenże, Janusz Dunin, czyli profesor od „złej literatury", [online] [dostęp: 01.09.2013]. Dostępny WWW: http://lodz.gazeta.pl/lodz/1,35135,9852245,Janusz_Dunin_czyli_profesor_od_zlej_literatury_html

${ }^{38}$ Po latach wspominał: „Nie istniała jeszcze wtedy w Polsce próba szerszego potraktowania zjawiska, traktowano je albo po tuwimowsku, jak ciekawostkę albo pisano artkuły ostrzegające przed zagrożeniem, jakie płynie z czytania tej tandetnej literatury. Działacze oświatowi i literaci ubolewali nad jej poziomem. Moją tezą było, że piśmiennictwo to, co prawda prymitywne i niekiedy żenujące, jeśli było kulturalnym bandytą, to przecież nie tak szkodliwym i zabójczym, bo papierowym"; J. Ladorucki, Pozostawałem w kręgu... s. 35.

39 Zob. na ten temat: J. Ladorucki, Janusz Dunin: badacz osobny..., passim. 
przypadku wykorzystywany w niewielkim zakresie. Ogromne znaczenia miała za to aktywność kolekcjonerska i sposób doświadczania świata kultury poprzez nią. Praktyka kolekcjonowania była zatem „,faktem antropologicznym" ${ }^{40}$ oddającym szczególny stosunek badacza do obiektów (druków) i podkreślającym swoisty naukowy użytek, jaki z nich czynił. Dunin nadawał więc bezwartościowym pojedynczo przedmiotom (pospolitym drukom) wartość w tworzonych kolekcjach, które zebrane ukazywały zjawiska w rozwijającej się żywo, na przełomie XIX i XX wieku, kulturze druku. Widać to szczególnie wyraziście poprzez typologie, odmiany i gatunki publikacji ujawniane (i scalane) w kolekcjach: pieśni jarmarcznych (łączących „elementy cudowności z fabułą iście kryminalną"41), piosenek kabaretowych, ballad podwórkowych o tematyce miłosno-kryminalnej, senników, ksiąg magicznych, serii i powieści zeszytowych (Buffalo Bill, Sherlock Holmes, Lord Lister), wysokonakładowych publikacji jarmarcznych (opowieści o Sowizdrzale, Magielonie, Meluzynie, Rinaldo Rinaldinim i świętej Genowefie). Procedura badania poprzez kolekcję bibliofilską była już na etapie zbierania materiałów generowanym przez zbieracza-uczonego procesem kulturowym, który w konsekwencji miał przysłużyć się oglądowi określonego wycinka współczesności bądź historii kultury. Ostatecznie $P a-$ pierowy bandyta, poprzez niestandardowe podejście autora stał się książką chętnie analizowaną, dyskutowaną i cytowaną; był prawdopodobnie jedynym bestsellerem bibliologicznym wśród powojennej, naukowej literatury humanistycznej.

Rozpoznawanie i poszukiwanie literackich odmienności oraz nietypowych publikacji na stałe zdominowało zainteresowania i karierę naukową uczonego. Nawet powierzchowny, bibliograficzny przegląd problemów badawczych podejmowanych przez Dunina daje wrażenie obszernego katalogu tematów. Uczony patrzył na zagadnienia kultury książki całościowo, katalogując jej różnorodność, wychwytując zjawiska, i otwierając tematy naukowe dla innych badaczy. Tak dzieje się w przypadku wspomnianej rozprawy Rozwoju cech wydawniczych polskiej książki literackiej XIX i XX wieku, którą należy traktować jako pracę teoretyczną, ale w dużym stopniu również jako „mapę” badań bibliologicznych na przyszłość. Ujawnia się tutaj pewnego rodzaju holistyczne podejście uczonego, który proponował syntezę charakterystyczną dla humanisty dostrzegającego wielość dziedzin

${ }^{40}$ Określenie Krzysztofa Pomiana. Zob.: Tenże, Zbieracze i osobliwości. Paryż. Wenecja XVI-XVII wiek, przeł. A. Pieńkos, Warszawa 1996, s. 12-13.

${ }^{41}$ J. Dunin, Papierowy bandyta. Książka kramarska i brukowa w Polsce, Łódź 1974, s. 37. 
kultury duchowej, a w niej książkę - element służący upowszechnianiu wartości i tradycji, trudny do „wypreparowania” z całościowego systemu kultury dla wycinkowych celów naukowych.

\section{VIII.}

Profesor Janusz Dunin w ujęciu autora niniejszego artykułu jawi się głównie jako badacz różnorodności i odmienności w obrębie zinlibrizowanych form pisma. Różnorodność w znaczeniu antropologicznym wskazuje na wielość sposobów organizowania życia i na to, „dlaczego mówimy i działamy w tak wielu językach" - stwierdza badacz kultury ${ }^{42}$. Bibliolog mógłby dołączyć do tego pytania o wielość form komunikacji poprzez książkę, sens jej fizyczności i przemian w tym zakresie, ewolucję technik wytwórczych i lekturowe konwencje oraz związane z nimi wartości społeczne. W gruncie rzeczy zachodzi tutaj podobieństwo celów i perspektyw. Klasyk myśli antropologicznej, Ruth Benedict, charakteryzując swoją dziedzinę, stwierdza, iż „koncentruje ona swą uwagę na cechach fizycznych i technikach wytwórczych, na tych konwencjach i wartościach, które odróżniają daną społeczność od wszystkich innych, posiadających różne od niej tradycje"43. W bibliologicznym systemowym podejściu do odczytywania zjawisk kultury poprzez książkę widoczne są tendencje do charakteryzowania podkultur czytelniczych określonych obiegów literackich, które wykształciły odrębne instytucje uczestnictwa i typy uczestników (odbiorców i nadawców). Dunin, inspirowany zapewne wcześniejszymi badaniami Stefana Żółkiewskiego ${ }^{44}$, szkicował charakterystyki czytelnicze bibliofilów, repatriantów, mniejszości językowych ${ }^{45}$. Spojrzenie bibliologa dawało w tym wypadku efekt w postaci unikatowego opisu zjawiska z pozycji badacza i uczestnika określonej formy komunikacji społecznej - te właśnie cechy twórczości naukowej Dunina, w opinii autora niniejszego artykułu stanowią szczególną zachętę do podejmowania analiz twórczości naukowej łódzkiego badacza.

42 E. Leach, Antropology [w:] Social Sciences Today, red. P. Barker, London 1975, s. 11 (cytat za: E. Nowicka, Świat człowieka - świat kultury. Systematyczny wykład problemów antropologii kulturowej, Warszawa 2004, s. 16-20.

${ }^{43}$ R. Benedict, Wzory kultury, przeł. J. Prokopiuk, Warszawa 1966, s. 63.

${ }^{44}$ S. Żółkiewski, Kultura czytelnicza 1918-1932, Wrocław [etc.] 1973, s. 434-461.

${ }^{45}$ J. Dunin, Pismo zmienia świat..., s. 112-121. 


\begin{abstract}
Anthropological stories of Janusz Dunin's bibliology

Profesor Janusz Dunin (1931-2007) was a humanist, an academic lecturer and a social activist. In his research he combined on a book a few parallel discourses: bibliology, bibliophily. He was interested in the social functioning of the contexts of publications and the evolutions of consumer strategies for reading as a human activity. The article refers to the modern theory of books and bibliology relationships with other areas. In a number of his scientific publications we can find the expressions of diversity research. Dunin traces culture books and trying to attempt to find their reflection of human behaviour. The outline of anthropological theory proposed by Dunin's book is a search for an interesting example of the borders of contemporary book science research and voice in the debate about the identity of the science of book.
\end{abstract}

